\title{
Access to information: Information disclosure in some South African organisations
}

\author{
R. van der Walt* \\ Department of Human Resources Management, University of Pretoria, \\ Private Bag X1311, Silverton 0127, Republic of South Africa \\ ruan.vanderwalt@up.ac.za
}

Received September 2006

\begin{abstract}
Legislation such as the Labour Relations No 66 of 1995 and the Promotion of Access to Information Act No 2 of 2000 has paved the way for creation of a culture of un-coerced disclosure of information in South African organisations. The article reviews progress in respect of information disclosure in South Africa and other countries and discusses the effects of the LRA in regard to disclosure of information to trade unions and workplace forums. It then describes a study conducted by the author and discusses the findings. It concludes with pointing out certain weaknesses in the disclosure process and exhorts managements and the trade unions to work together to improve this important tool for achieving success in organisations and enhancing industrial democracy.
\end{abstract}

*To whom all correspondence should be addressed.

\section{Introduction}

Most South Africans are familiar with the deplorable and sometimes tragic events of the recent past, committed in culture of secrecy and bureaucracy. Some of these tragedies could possibly have been prevented had a system of access of information been in place during the previous political dispensation. It is therefore understandable that the African National Congress (ANC) government wanted to transform society to a state in which the rule of law and a democratic constitution stands supreme.

In order to achieve the desired transformation of society the government makes use of various legislative measures. Foremost of these is the Constitution of the Republic of South Africa Act No 108 of 1996 (hereafter referred to as the Constitution).

Section 32(1) of the Constitution provides that everyone has the right of access to any information held by the state and to any information that is held by another person and that is required for the exercise or protection of any rights. This means, for example, that employees have the right of access to information held by their employers.

Section 32(2) of the Constitution stipulates that national legislation must be enacted to give effect to the right provided for in section 32(1). This was done by the enactment of the Promotion of Access to Information Act No 2 of 2000 (PAIA). This Act came into effect on 9 March 2001. (The South African Human Rights Commission (SAHRC) has published a Guide on how to use the Promotion of Access to Information Act No 2 of 2000).

Other legislation that deals with access to information, particularly in the work situation, is section 16 of the Labour
Relations Act No 66 of 1995 (LRA).

In terms of section 51 of the PAIA all private bodies in the Republic are required to compile a manual which contains information on how to use the PAIA to access the records held by such private bodies. In practice this meant that even a street vendor had to submit a manual by a prescribed date. This was clearly an onerous burden on entrepreneurs and small businesses, parties which the government wants to encourage, promote and support (Barnard, 2005:11). All public bodies are required to have manuals in terms of section 14. Originally the Minister of Justice and Constitutional Development exempted all private bodies from compiling a manual for submission to the SAHRC until 31 August 2005. After private organisation had gone to considerable expense to have manuals compiled, the Minister issued a last-minute extension for the submission of manuals. In terms of this extension, for example, a farmer with fewer than 50 employees and an annual turnover of less than R2m is exempted until 31 December 2011(Monteiro, 2005:25 and SAHRC Media Release, 7 September 2005).

Legislation and judicial rulings dealing with information disclosure emerged at different times in different countries. In the United States of America (USA) it dates back as far as 1936 when the National Labour Relations Board (NLRB) (similar to the Commission for Conciliation Mediation and Arbitration (the CCMA) in South Africa) recognised that disclosure of information was important for collective bargaining purposes. It is rather ironic that the USA which prides itself on its democratic values is currently experiencing deep divisions in society due the policies of President George W. Bush's administration and such acts as the United States patriot Act (Holovach, 2005:4) The above mentioned act places tremendous restrictions on the lifestyle 
which citizens of the USA have come to accept as an inalienable right. For example, freedom of movement at airports is now restricted through tighter security measures.

In the United Kingdom (UK) legislation was introduced in 1971 which compelled employers, when requested, to provide trade unions with the kind of information without which collective bargaining would be impeded. The UK approved its Freedom of Information Act No 2 of 2000 in November 2000 (Kollapen, 2005: 3). But this Act only came into effect on 1 January 2005. Most European countries have a works council system with statutory provisions for disclosure of information. In Sweden after the Second World War, the disclosure of information was regulated by a voluntary national agreement between the Swedish Confederation of Employers' Organisations (SAF) and the Confederation of Trade Unions (LO). This arrangement was replaced by the Joint Regulation of Working Life Act in 1977 which provides for wide-ranging statutory rights to information (Ballace \& Gospel, 1983).

The developments surrounding the disclosure of information at the workplace in the UK and the European Union (EU) cannot be viewed in isolation as it has come about as a result of EU policies and European social laws. The EU's policies and social laws have given rise to a social dialogue in the EU as well as in the UK. Carby-Hall (2006:430) writes that various aspects of the social dialogue such as information, consultation, collective bargaining etc 'form the very fabric of law, justice and democracy in European and British industrial relations all of which spell industrial democracy'.

In chapter IV, the so-called Solidarity chapter the Charter of Fundamental Rights of the European Union (OJ, 2000a) in Carby-Hall (2006:445) states that 'workers or their representatives must be guaranteed information and consultation in good time in cases and the conditions provided for by the Community law and national laws and practices' (OJ 2000b) in Carby-Hall (2006:445).

On an international level organisations such as the International Labour Organisation (ILO), the Organisation for Economic Co-operation and Development (OECD), the United Nations Commission on Transformational Corporations and the European Community/Union have all contributed to a greater awareness of the importance of disclosure of information to the representatives of the workers (Roberts \& Liebhaberg, 1977).

Trade unions view information disclosure as a means of furthering their objectives by extending negotiations and joint regulation into areas that were previously the exclusive domain of management. European unions also regard disclosure of information as a means of broadening industrial democracy (Ballace \& Gospel, 1983). On the other hand some employers regard statutory obligation of disclosure to trade unions as a threat to their management prerogative. Their objections are based on the need for commercial secrecy and confidentiality and fear that effective decision-making will be impeded (Van der Walt, 2002: 90-105). Other more progressive employers welcome greater disclosure as a channel of communication with their employees.

\section{Problem statement}

To determine to what extent the disclosure of information in the workplace enables unions, employee' representatives and managements to bargain in an informed manner.

\section{The origin of disclosure of information in South Africa}

Since 1994 the South African government has actively attempted to foster a culture of transparency and accountability in public and private organisations by giving effect to the right of access to information. In effect section 8 of the Constitution 'provides for the horizontal application of the rights in the Bill of Rights to juristic persons to the extent required by the nature of the rights and the nature of those juristic persons' (Quoted in the Promotion of Access to Information Act No 2 of 2000). Furthermore section 32(1) (a) of the Constitution provides that everyone has the right of access to information held by the State and section 32(1) (b) in effect 'provides for the horizontal application of the right of access to any information held by another person to everyone when that information is required for the exercise or protection of any rights' (Quoted in the Promotion of Access to Information Act No 2 of 2000). Section 32(1) (b) means that employees and trade unions have constitutional support when they demand information from their employers in order to exercise or protect their rights. The Constitution requires the government to enact national legislation to give effect to the rights stipulated in Section 32 of the Constitution and this has taken the form of the Promotion of Access to Information Act No 2 of 2000.

Landman (1996:22) is of the opinion that the rationale for disclosure of information can be divided into two aims: the employee-centred aim and the company-centred aim. He writes 'Parliament believes that employees and their agents will be able to perform their monitoring functions, exert influence on managerial discretion and make decisions on a higher and more informed perhaps even rational basis if they are provided by employers with relevant knowledge and information'. Based on his research Grosett (1997:37) provides the following reasons for business information disclosure and writes that 'employee-centred aims are based on more 'ethical' considerations such as the organisation's responsibility to keep its employees informed and the desirability of employees' representatives to be given information to support the role of joint consultation and other forms of participation in decision-making '.

In dealing with their employers, employees nowadays regard access to business information as essential in order for them to gauge the employer's financial position, as well as the employer's ability to meet with their demands. Some employers in turn regard the disclosure of business information as a further opportunity to increase their influence on and control of the workplace. In this regard Grosett (1997: 37) writes that the aim of information disclosure is to 'reinforce management's influence and control of the organization .... achieved by increasing employee involvement and identification with the interests of the organization'. However, not all employers view disclosure of information as an opportunity - some see this 
as a definite threat to their 'management prerogative' and fear that it could lead to an escalation in demands from employees.

Grosett's (1997:38) research of South African organisations found the following benefits of information disclosure as indicated by employers: 1) Employers believe that information disclosure leads to improved employee cooperation because information enhances the employees' understanding of the organisation and decisions made within it. 2) Employers were also of the opinion that shared information leads to improved collective bargaining and reduced conflict. 3) Employers also reported increased employee involvement in decision-making because employees had access to relevant information. 4) A further reported benefit was increased levels of job satisfaction.

\section{Development in other countries}

The disclosure of information in collective bargaining and the consultation process has long found acceptance in other countries as pointed out briefly above. Brand and Cassim (1980:250) writes 'The progress of collective bargaining in the United States and Europe has been characterised by the move away from uninformed and irrational bargaining towards sophisticated and intelligent bargaining. In the USA this process has been facilitated by a recognition that, integral to the duty to bargain, is the requirement that an employer furnish relevant information in its possession to the union. The purpose of this is to enable the union to bargain intelligently, to understand and discuss issues raised by the employer's opposition to the union's demands and administer a contract'.

Jordaan (1996:1-2) quoting a report issued by the Advisory, Conciliation and Arbitration Services in the UK writes that a lack of information has been shown to handicap the ignorant party when it comes to the bargaining and consultation process. Automatic disclosure of information to works councils in Germany and the Netherlands is common practice.

The International Labour Organisation (ILO) also recommends that disclosure of information should be part of the collective bargaining process. The ILO's Collective bargaining standards recommendation (1981: 163) reads 'measures adapted to national conditions should be taken, if necessary, so that parties have access to information required by meaningful negotiation'.

As indicated above, the developments regarding the disclosure of information in the UK and the EU should be seen against the background of the EU's policies and social laws which has resulted in a social dialogue in the EU and the UK which amongst other issues re-examines industrial democracy.

The need for the development of a culture of information disclosure in South Africa must be seen against the background of a system of government which prevailed for decades and over time resulted in a secretive and unresponsive culture in public and private bodies and which in turn led to abuse of power and human rights. Some South
Africa organisations are still struggling to come to terms with the fact that democratic values and expectations also extended into the workplace.

\section{Contribution of legislation}

The provisions for information disclosure contained in the Labour Relations Act No 66 of 1995, the doctrine of discovery in law practice, i.e. the obligation on opposing sides to disclose documents that they may have in their possession and the Constitution of the RSA have all contributed to the development of a culture of information disclosure. Johannessen (1995:45) identified the following reasons for access to information under section 23 of the Constitution of the Republic of South Africa Act 200 of 1993 (the Interim Constitution): 1) Access to information is a right identified in the chapter on fundamental human rights in the Constitution. 2) Allowing citizens to obtain information is an essential part of democratic participation and the free flow of information supports the participatory form of democracy. 3) Access to information encourages accountability in a democracy and also encourages better administrative decisions.

The reasons for gaining access to information mentioned above reflect the importance of information disclosure in any constitutional democracy. This right of access to information is of such importance that it is specified in the final Constitution. Section 32 of the Constitution of South Africa Act No 108 of 1996 deals specifically with this very important right. In his commentary on section 32, Devenish (1998:80) writes 'Its inclusion endorses the pervasive theme of accountability and transparency of government and administration that runs like a golden thread through the entire Constitution and forms part of a new political morality'. It follows that without information disclosure employees, for example, would find it impossible to hold employers accountable for actions that are detrimental to employee interests.

In South African labour law the right to disclosure of information was in the past advanced through the principle of good faith bargaining and Industrial Court decisions regarding retrenchment. Kahn-Freund (1977:21) has written that 'Negotiation does not deserve its name if one of the negotiating parties is kept in the dark about matters within the exclusive knowledge of the other which are relevant for agreement'.

Collective bargaining, it could be argued is the very essence of industrial relations and an important institution in all democratic societies where freedom of association is accepted. Dubin (1954) has suggested that without collective bargaining, industrial conflict would threaten not only the industrial order but also social stability. Collective bargaining is the main method whereby unionised employees and their managements determine such matters such as pay and conditions of service. Without the disclosure of information by both sides, collective bargaining will be very difficult. 


\section{The LRA no 66 of 1995 and its consequences for disclosure of information}

Disclosure of information is provided for in section 16 of the above Act in order for the LRA to achieve its objectives of promoting collective bargaining and employee participation. Section 16(1) specifies that disclosure of information can only be claimed by a majority union. However, minority unions may act together to achieve a majority and then exercise their right to disclosure. Section16 (2) requires that the employer must disclose to a trade union all relevant information. Du Toit, Woolfrey, Murphy, Godfrey, Bosch and Christie (2000:176 and 1998:114) under the heading 'Disclosure of Information', write that 'Once a union has acquired this right, the onus is on the employer to disclose the required information, even in the absence of any request from the union'.

In this context, 'this right' means that the trade union concerned has achieved representative status. The 'required information' refers to disclosure of relevant information to the union that will allow its representatives to effectively perform their functions and enable it to engage effectively in consultation and collective bargaining in terms of the relevant sections of the LRA.

The voluntary disclosure of information by employers during collective bargaining and participation by employees in decision-making may be the process of action that is required to improve and strengthen the trust relationship between employers and trade unions in South Africa.

Successful consultation and joint decision-making processes depend largely on the knowledge the parties have about the issues being discussed. It is for this reason that the legislature has granted Workplace Forums (WPFs) (similar to works councils) the right to information in terms of section 89 of the LRA. The employer must disclose to the Workplace Forums all relevant information that will allow the Workplace Forums to accomplish effective consultation and joint decision-making.

An employer with a functioning Workplace Forum has to disclose all relevant information. The relevance is determined by reference to the matters listed for consultation in section 84 and for joint decision-making in section 86. The Workplace Forums may request further disclosure except in respect of information that is legally privileged and information that cannot be disclosed as such disclosure would contravene the law or an order of the court. Disclosure of information that may cause substantial harm to an employee or employer and private and personal information is also excluded.

\section{Relevance of information}

Everingham (1991:217) suggests that, in general, the following information should be disclosed: 1) Information on the financial status of the organisation; 2) information on absenteeism; 3) industrial relations and productivity; and lastly, information on the employees' contribution to the planning of the organisation's future. This suggestion includes the typical information found in annual reports of companies. In the current writer's opinion it is doubtful whether disclosure of this type of information which is mainly designed to meet the requirements of the company's shareholders, will contribute to more constructive collective bargaining and greater employee participation in decisionmaking.

Based on the research of information disclosure to employees, Grosett (1997:39-40) lists the following items of information which should be disclosed: productivity information; information on morale; information on wages and benefits; safety information; information on company performance; information on wealth-sharing and information on the organisation's future.

In regard to disclosure to representative trade unions in terms of section 16 of the LRA, the question of whether or not information is relevant is determined with reference to the circumstances of each case. Furthermore the relevance of information must be determined by the purpose for which it is sought and it must be pertinent to the issues under discussion.

It should be clear that from the preceding review that disclosure of information plays a crucial role in labour relations in most industrialised countries. As a developing and newly industrialised country, South Africa has securely anchored democratic ideals in its constitution as well as in its labour legislation such as the Labour Relations Act. This bodes well for the future.

The aim of this article is to obtain some idea of the extent to which these ideals for greater disclosure of information in the workplace such enabling unions to bargain intelligently and understand issues raised by employers, have already found practical application. The discussion is based on the findings of a study conducted by the writer in a number of organisations. The research method, results and conclusions are discussed in the following sections.

\section{Research method and results}

\section{Research method}

An extensive investigation including an in depth literature study was conducted by the author to obtain appropriate background for the execution of the research.

In the current study the author employed the qualitative analysis approach expounded by Miles and Huberman in their 1984 and 1994 book Qualitative data analysis: A source book of new methods. This book is described by Punch (2005:197) as a comprehensive source book which is aimed 'at tracing out lawful and stable relationships among social phenomena, based on the regularities and sequences that link these phenomena'. This method of data analysis entails concurrent processes of activity, namely data collection, data reduction, data display, verification, and drawing conclusions. Due to the interactive nature of this research model it is possible for example, that data reduction and data display could take place concurrently. The process of qualitative data analysis and interpretation is described appropriately by Cresswell (1998: 142-165) as a spiral 
image - a data analysis spiral.

\section{Data collection}

Based on the prior investigation of data collection methods, a survey questionnaire and in-depth interviewing procedures within the qualitative research tradition were developed from relevant literature.

Research data were obtained from seven organisations which agreed to participate in the study. (It is much regretted that in many instances few organisations are prepared to participate in research which could be of benefit to themselves, wider society and the state.) These seven organisations were part of a group of organisations who had registered a Workplace Forum with the CCMA. The participating organisations (referred to in the study as 'cases') were members of various sectors of the economy, viz. agricultural research (case A). tertiary education (case $B$ ), private security industry (case $C$ ), manufacturing (case D), research and development ( cases E), private hospital (case F) and the armaments industry (case G). All seven of these cases were located in the Gauteng Province. Stake (in De Vos, Strydom, Fouche \& Delport (2005: 272)) argues that the sole criteria for selecting cases for a case study should be 'the opportunity to learn'. In others word does a case contribute to the understanding of the area of study.

One of the criteria for good qualitative research, namely generalizability, as suggested by Lincoln and Guba (1985:20) was applied in the study by means of triangulation of multiple sources of data. This was achieved by requesting each participating organisation to complete two questionnaires, one by management representatives and one by worker representatives. Management respondents were required to describe the views of management in their respective organisations and worker representatives (usually shop stewards) the views of the workers in the corresponding organisations. The outcome of this process was that multiple views were obtained in each case as well as multiple views across the different cases in the seven sectors of the economy.

In addition to obtaining the above information the researcher also obtained where possible, the agendas, minutes of meetings and any other documents pertaining to the interaction between management and workers.
Further data for analysis were obtained from in-depth interviews with respondents who were amenable to and available for requests for explanatory data.

\section{Data reduction}

This component of the qualitative analysis process refers to selecting and transforming the 'raw' data recorded in written field notes or other sources of data so that it could be utilized for research purposes. Data reduction occurs continuously throughout the duration of any qualitative oriented research project. In the qualitative analysis process this often starts when a researcher decides which conceptual framework, which sites, which research questions and which data collection approaches to utilize. Data reduction further entails such activities as making summaries, coding, eliciting themes, making data clusters and partitioning data. Data is further reduced through focussing and bounding the research and generally consists of building a conceptual framework, formulating research questions, sampling and instrumentation (Miles \& Huberman, 1984: 36).

A conceptual framework explains either graphically or in a narrative form, the main dimensions to be studied - the key factors or variables and the presumed relationships. A framework can be rudimentary or elaborate, theory driven or commonsensical, descriptive or causal. Using the method suggested by Miles and Huberman (1984: 28; 1994:18) the current researcher developed a conceptual framework, Figure 1 for purposes of the entire study of which Disclosure of Information formed part.

The four aspects of industrial democracy shown in the conceptual framework, Figure 1, namely, Disclosure of Information, Collective Bargaining, Worker Participation and Workplace Forums were selected for study after a comprehensive review of relevant literature and current labour relations practice in South Africa. This article focuses only on Disclosure of Information as the research question. A range of pertinent sub-questions formed part of the structured interview schedule required to be answered by both a management representative and an employee representative in each of the organisations included in the study. 


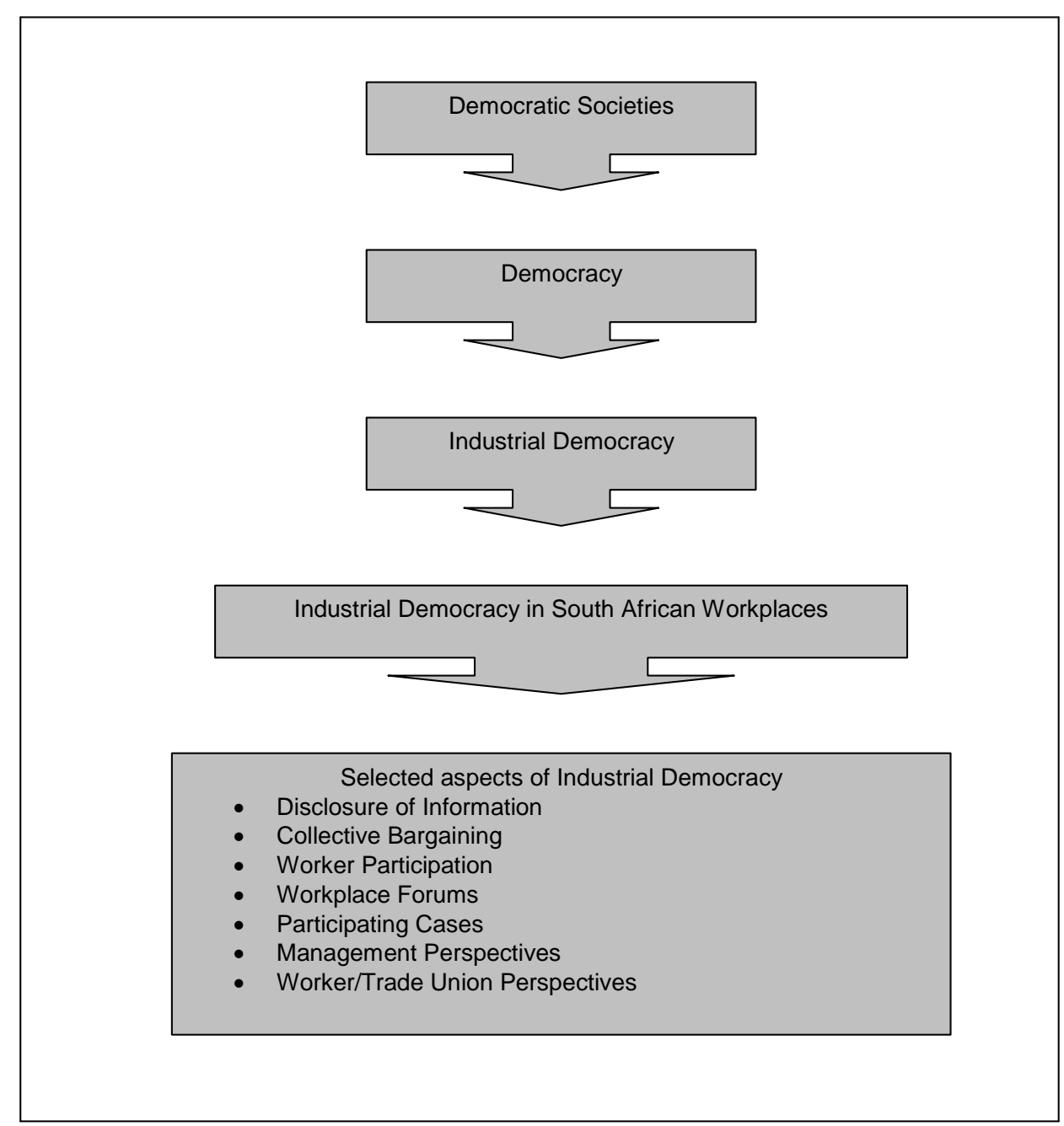

Figure 1:Conceptual framework

Advancement of industrial democracy is one of the primary objectives of the LRA of 1995. The LRA made provision for the establishment of the Commission for Conciliation, Mediation and Arbitration (CCMA) whose function inter alia is to facilitate the establishment of Workplace Forums (WPFs). WPFs are the vehicle of choice to institutionalise industrial democracy in South African workplaces

Trade unions which have achieved representative status in their respective organisations and wish to establish a WPF, have to apply to the CCMA. Unfortunately many applicants have failed to fulfil all the statutory requirements for registration and statutory requirements for registration and statutory recognised WPFs could thus not be established. Wood and Mahibir (2001:241) have also found a sparsity of Workplace Forums.

Consequently when in the mentioned study, the sampling activity commence, reference was made to a report of the CCMA to establish which WPFs could be involved in the investigation. For convenience sake the Gauteng Province was selected as the setting for the investigation because it was the province with the greatest economic activity. Even so it was found from the CCMA report that only seventeen WPFs which could be used as case studies had been registered in Gauteng. Of these, one organisation could not be used for research purposes as the contact details were incomplete; some organisations had ceased business; others were committed to other research or were not interested in participating in the proposed study. This left only two organisations which were too few cases even for a qualitative study.

It was then decided to approach other organisations which had subsequently been placed on the CCMA's register or met the requirements for registration but for various reasons had decided not to apply for registration. In this manner five more cases were added to the study.

In the current study the data from the questionnaires (see under section 4.1.1) was reduced through the following steps. The data from each questionnaire was analysed and summarised to construct one worksheet with responses of the management and the trade union/worker representatives for each organisation. Relevant additional information from agendas, minutes of meetings, memoranda etc. were also recorded on the worksheets. From the worksheets the data was transferred to displays such as the various tables and lists discussed below.

\section{Data display}

The first step to display the data in the current study was to construct a cross-case compilation of the management and 
the worker views on the four selected aspects of industrial democracy which formed part of the larger study. Only examples of data displays of one of these aspects, namely disclosure of information are presented in this article. Miles and Huberman (1994:178) refer to these cross-case displays as meta-matrices. They are master charts that gather descriptive data from each of several cases in a uniform format. Table 1 (below) illustrates the result of this step.

Having completed the meta-matrices each question's data was displayed in either a list or in a table format. This was done in respect of the responses of both management representatives and worker representatives: (See question 1 and question 2 below). Due to space limitation only one example of each display format is given.

\section{Data analysis: conclusion drawing/verification}

In regard to drawing and verifying conclusions Miles and Huberman (1994:245) note that 'people are meaningfinders; they can very quickly make sense of the most chaotic events'. It is of utmost importance that the meanings which the researcher finds in qualitative data should be valid, repeatable and right. The abovementioned authors have suggested a number of tactics for confirming, avoiding bias and assuring the quality of conclusions of qualitative data by means of noting patterns, themes; seeing plausibility; clustering; making metaphors; making contrasts/comparisons; partitioning variables; subsuming particulars into the general; factoring; noting relations between variables; finding intervening variables; building a logical chain of evidence and making conceptual/ theoretical coherence. Where applicable some of these techniques were used in the discussion of results and the drawing of conclusions in the current study.

\section{Analysis of data and results}

Once the questionnaires were completed and the relevant documents were received, the responses of the two groups of representatives were summarised and tabulated. In a number of cases it was necessary to conduct follow-up interviews to clarify certain responses. The responses to each of the survey questions and sub-questions on the selected aspects of industrial democracy were recorded and tabulated prior to analysis.

Table 1: Compilation of all management representatives' responses on disclosure of information (DOI) (TU = Trade Union; CB = Collective Bargaining; ; WPF = Workplace Forum; LRA = Labour Relations Act)

\begin{tabular}{|c|c|c|c|c|}
\hline Research Questions & Case A & Case B & Case C & Case D \\
\hline $\begin{array}{l}\text { 1. View of s16 of } \\
\text { LRA. }\end{array}$ & $\begin{array}{l}\text { Open to idea. } \\
\text { Enhances consultation. }\end{array}$ & $\begin{array}{l}\text { Agrees with s16 as long as } \\
\text { focuses are on relevant } \\
\text { info. }\end{array}$ & $\begin{array}{l}\text { Only disclosed if } \\
\text { necessary to assist our } \\
\text { employees. }\end{array}$ & $\begin{array}{l}\text { Disclose what } \\
\text { TUs/employees want if } \\
\text { reasons are justified. }\end{array}$ \\
\hline $\begin{array}{l}\text { 2. Who makes } \\
\text { requests for } \\
\text { DOI. }\end{array}$ & TU reps or employees. & $\begin{array}{l}\text { TUs, staff members and } \\
\text { WPF reps. }\end{array}$ & $\begin{array}{l}\text { TUs, staff members and } \\
\text { WPF reps. }\end{array}$ & $\begin{array}{l}\text { Requested via internal } \\
\text { forum and supported by } \\
\text { real need for info. }\end{array}$ \\
\hline $\begin{array}{l}\text { 3. TU limited to info } \\
\text { on members only. }\end{array}$ & $\begin{array}{l}\text { Yes, limited TU members } \\
\text { only. }\end{array}$ & $\begin{array}{l}\text { No, should have clear } \\
\text { picture of organisation's } \\
\text { ability to participate } \\
\text { responsibly. }\end{array}$ & $\begin{array}{l}\text { Yes, non-members } \\
\text { have right to } \\
\text { confidentiality of their } \\
\text { info. }\end{array}$ & $\begin{array}{l}\text { No, would not be } \\
\text { sufficient. A thoroughly } \\
\text { thought-out approach } \\
\text { implemented uniformly is } \\
\text { required. }\end{array}$ \\
\hline $\begin{array}{l}\text { 4. Improved CB and } \\
\text { conflict resolution? }\end{array}$ & $\begin{array}{l}\text { Yes, positive influences } \\
\text { on CB and conflict } \\
\text { resolution. }\end{array}$ & $\begin{array}{l}\text { Yes, better understanding } \\
\text { of organisation's } \\
\text { limitations. }\end{array}$ & $\begin{array}{l}\text { No, explanation by } \\
\text { management usually } \\
\text { sufficient. }\end{array}$ & $\begin{array}{l}\text { Not really, honesty and } \\
\text { transparency not } \\
\text { appreciated by TUs. }\end{array}$ \\
\hline $\begin{array}{l}\text { 5. Effect on } \\
\text { employee } \\
\text { participation? }\end{array}$ & $\begin{array}{l}\text { Yes, positive influences } \\
\text { on employee participation. }\end{array}$ & $\begin{array}{l}\text { Positively, better } \\
\text { understanding and } \\
\text { problem-solving. }\end{array}$ & $\begin{array}{l}\text { Not sure if disclosure has } \\
\text { had effect. }\end{array}$ & $\begin{array}{l}\text { Once info is received by } \\
\text { TU that is normally the end } \\
\text { of request due co.'s honesty }\end{array}$ \\
\hline $\begin{array}{l}\text { 6. Type of info } \\
\text { disclosed. }\end{array}$ & All relevant info. & $\begin{array}{l}\text { Salary, budget strategies, } \\
\text { all management info at } \\
\text { appropriate time. }\end{array}$ & $\begin{array}{l}\text { Vacancies, company } \\
\text { notices. }\end{array}$ & $\begin{array}{l}\text { Non-sensitive: marketing, } \\
\text { finance, production, co. } \\
\text { performance etc }\end{array}$ \\
\hline $\begin{array}{l}\text { 7. Stage/when } \\
\text { disclosure takes } \\
\text { place. }\end{array}$ & $\begin{array}{l}\text { When requested/deemed } \\
\text { necessary by management. }\end{array}$ & $\begin{array}{l}\text { When they ask or when } \\
\text { we think it can assist the } \\
\text { process. }\end{array}$ & $\begin{array}{l}\text { Only if the majority of } \\
\text { employees are in } \\
\text { agreement that info is } \\
\text { needed by employees. }\end{array}$ & $\begin{array}{l}\text { Need to know basis. By } \\
\text { delaying disclosure it } \\
\text { appears as if info becomes } \\
\text { more important to TUs }\end{array}$ \\
\hline $\begin{array}{l}\text { 8. Disputes re } \\
\text { disclosure of info. }\end{array}$ & No disputes so far. & $\begin{array}{l}\text { Not really. Handled } \\
\text { in-house. }\end{array}$ & No disputes. & $\begin{array}{l}\text { Yes, info verified by CA } \\
\text { under auspices of CCMA. }\end{array}$ \\
\hline $\begin{array}{l}\text { 9. Resolve disputes? } \\
\text { Process used. }\end{array}$ & N/A & $\begin{array}{l}\text { Negotiation between } \\
\text { employer and TU. }\end{array}$ & N/A. & Arbitration of CCMA \\
\hline
\end{tabular}


Table 1 (continued)

\begin{tabular}{|c|c|c|c|}
\hline Research Questions & Case E & Case F & Case G \\
\hline 1. View of s16 of LRA. & $\begin{array}{l}\text { In terms of agreement } \\
\text { between TUs and } \\
\text { employer communication } \\
\text { means conveying and } \\
\text { disclosure of info at the } \\
\text { earliest possible time } \\
\text { before acting. }\end{array}$ & $\begin{array}{l}\text { Agree with principle expressed in } \\
\text { s16 }\end{array}$ & $\begin{array}{l}\text { We share business processes } \\
\text { and financial information }\end{array}$ \\
\hline $\begin{array}{l}\text { 2. Who makes requests for } \\
\text { DOI. }\end{array}$ & Chairperson of WPF. & $\begin{array}{l}\text { Employees and/or union } \\
\text { representatives }\end{array}$ & $\begin{array}{l}\text { The union and people needing } \\
\text { information }\end{array}$ \\
\hline 3. TU limited to info on members only. & $\begin{array}{l}\text { Yes, Personal info limited } \\
\text { to TU members. } \\
\text { Remuneration info } \\
\text { disclosed during wage } \\
\text { negotiations. }\end{array}$ & $\begin{array}{l}\text { Yes, info must be limited to TU } \\
\text { members only }\end{array}$ & $\begin{array}{l}\text { Yes, we apply this principle. } \\
\text { The union is not entitled to } \\
\text { info on non-members }\end{array}$ \\
\hline 4. Improved CB and conflict resolution? & $\begin{array}{l}\text { Yes, LRA is silent on info } \\
\text { sharing by TU to enable } \\
\text { employer to } \\
\text { bargain/consult } \\
\text { effectively. }\end{array}$ & $\begin{array}{l}\text { Yes, more info is available and } \\
\text { therefore better CB and conflict } \\
\text { resolution }\end{array}$ & $\begin{array}{l}\text { Not at first, later it improved } \\
\text { the collective bargaining } \\
\text { process }\end{array}$ \\
\hline 5. Effect on employee participation? & $\begin{array}{l}\text { Yes, forms part of } \\
\text { collective agreement } \\
\text { between TUs and } \\
\text { employer. }\end{array}$ & $\begin{array}{l}\text { Yes, employees are more involved } \\
\text { due to more info available to them }\end{array}$ & $\begin{array}{l}\text { No effect. Unions bargained } \\
\text { regardless of info. available }\end{array}$ \\
\hline 6. Type of info disclosed. & $\begin{array}{l}\text { All relevant info for } \\
\text { effective functioning: } \\
\text { closing/erection of plants, } \\
\text { org. restructuring, } \\
\text { promotion of employees. }\end{array}$ & $\begin{array}{l}\text { Financial info during wage } \\
\text { negotiation } \\
\text { Organisational restructuring }\end{array}$ & $\begin{array}{l}\text { Specific marketing, financial } \\
\text { situation, monthly sales } \\
\text { estimates, employment equity }\end{array}$ \\
\hline 7. Stage/when disclosure takes place. & $\begin{array}{l}\text { Usually during wage } \\
\text { negotiations }\end{array}$ & $\begin{array}{l}\text { During wage negotiations or when } \\
\text { requested }\end{array}$ & $\begin{array}{l}\text { On a continuous basis or } \\
\text { when requested }\end{array}$ \\
\hline 8. Disputes re disclosure of info. & No disputes & Yes, about financial info & No disputes to date \\
\hline $\begin{array}{l}\text { 9. Resolve disputes? } \\
\text { Process used. }\end{array}$ & N/A & $\begin{array}{l}\text { Conciliation and mediation at } \\
\text { CCMA }\end{array}$ & N/A \\
\hline
\end{tabular}

The responses of the worker representatives were compiled in a similar manner as above.

Listing or tabulation of responses

Question 1. 'Respondents' views of section 16 of the LRA providing for disclosure of information'.

Cases (Management representatives’ views)

A. Open to idea - enhances consultation

B. Agrees with s16 as long as focus is on relevant information

C. Only disclosed if necessary to assist our employees

D. Disclose what trade union (TU)/employees want if reasons are justified

E. In terms of agreement between TUs and employer communication means conveying and disclosure of info at earliest possible time before acting

F. Agree with principle expressed in s16 of LRA

G. We share business processes and financial information

Cases (TU/worker representatives' views)

A. In line with LRA. Means of solving disputes

B. Taken note and have made arrangements for disclosure of certain info. No info on remuneration of senior management
C. Good idea gives workers more insight

D. It gives the TU the right to information

E. Makes protecting interests of TU members much easier

F. Very important as it allows TU reps to perform functions

G. Gives TU more information than before

From an examination of the management representatives' views on section 16 of the LRA of 1995 it is clear that all seven respondents agree with the principle of disclosure of information. However, the application of the principle differs and appears to range from an open approach of sharing information to a narrow approach of disclosing only some information and only when requested by the trade union or workers as is indicated in cases C and D.

Judging from the responses, the worker representatives are in favour of the disclosure of information. This is to be expected as the workers and their representatives now have more information available than ever before, making their job of protecting the interests of workers so much easier and effective. Case B indicated that certain information is excluded from disclosure. This theme of reluctance to disclose certain information is repeated amongst the responses to question seven of this section. 
Question 2. 'Who should make such requests for disclosure of information?'

Table 2: Management representatives’ responses

\begin{tabular}{l|l|l|l|l|l|l|l}
\hline & A & B & C & D & E & F & G \\
\hline Trade union (TU) & $\mathrm{x}$ & $\mathrm{x}$ & & & & & $\mathrm{x}$ \\
\hline Employees & $\mathrm{x}$ & $\mathrm{x}$ & $\mathrm{x}$ & & & & $\mathrm{x}$ \\
\hline TU and employees & & & & & & $\mathrm{x}$ & \\
\hline Workplace Forum & & $\mathrm{x}$ & & & $\mathrm{x}$ & & \\
\hline $\begin{array}{l}\text { Other representative } \\
\text { body }\end{array}$ & & & & $\mathrm{x}$ & & & \\
\hline
\end{tabular}

The responses of the management representatives to the question of who should make the request is presented in Table 2. No clear pattern emerges from the responses plotted in the table, but it appears that the management representatives are in favour of the trade union and employees (or a combination of the two) making requests for the disclosure of information.

\section{Table 3: TU/worker representatives’ responses}

\begin{tabular}{l|l|l|l|l|l|l|l}
\hline & A & B & C & D & E & F & G \\
\hline TU Officials & $\mathrm{x}$ & $\mathrm{x}$ & $\mathrm{x}$ & & $\mathrm{x}$ & & \\
\hline $\begin{array}{l}\text { Elected } \\
\text { representatives }\end{array}$ & $\mathrm{x}$ & & & $\mathrm{x}$ & & $\mathrm{x}$ & $\mathrm{x}$ \\
\hline Councillors & $\mathrm{x}$ & & & & & & \\
\hline $\begin{array}{l}\text { Individual } \\
\text { employees }\end{array}$ & $\mathrm{x}$ & & $\mathrm{x}$ & $\mathrm{x}$ & & & \\
\hline $\begin{array}{l}\text { WPF } \\
\text { representatives }\end{array}$ & & & & & $\mathrm{x}$ & & \\
\hline Outside parties & & $\mathrm{x}$ & & & & & \\
\hline
\end{tabular}

From the responses in Table 3 it appears that worker representatives prefer that the elected or trade union representatives as well as individual employees make the requests for disclosure of information. It is interesting to note that there is strong agreement on this point between both management and worker representatives in spite of the fact that they serve different constituencies.

The responses to Question 3, 'Should trade unions be limited to information concerning their members only?' gave the following results:

The majority of management representatives held the view that information disclosed to the unions should be restricted to information concerning their members. However, there was also a view that information should not be so restricted. A management representative was of the opinion that worker representatives 'should have a clear picture of the organisation's ability to participate responsibly'. Such a view may be described as mature and progressive on the role of trade unions because it recognises their particular function in healthy labour relations.
As could be expected the workers representatives, almost without exception, believed that disclosure should not be limited to information concerning members only. This was hardly surprising as more available information could strengthen their union's bargaining position. One worker representative had reservations about unrestricted access to information. This concern related to possible abuse of confidential information.

Question 4 asked 'Has disclosure of information improved collective bargaining and conflict resolution processes in your organisation?' The responses of the management representatives presented a mixed picture - four reported improvement in collective bargaining and conflict resolution in their organisations and this was confirmed by the worker representatives in three of the same organisations.

The remaining three management representatives (cases C, $\mathrm{D}$ and $\mathrm{E}$ ) reported that disclosure of information had not contributed to improvement in collective bargaining and conflict resolution in their organisations. This view was confirmed by four of the worker representatives, including those of organisations C, D and E. These four based their views on reasons such as that the information disclosed was too selective and too limited to be of much use.

Employee participation in decision-making is a key element of industrial democracy and Question 5 therefore asked 'Has disclosure of information affected employee participation in your organisation?'

Four management representatives gave an outright positive response to the question. This finding corresponds with that of Grosett (1997:38) who found that one of the benefits of disclosure of information listed by employers was increased employee involvement. Five of the worker representatives also reported that the disclosure of information definitely improved employee participation in their organisations.

The responses from management and the worker representatives to Question 6, 'What type of information is disclosed?' indicated a wide range of categories. Most frequently requested and furnished were financial information or budgetary information. Disclosure of information on organisational changes and restructuring was second most frequent.

The LRA does not specifically indicate when information should be disclosed to a trade union or worker representatives. However, section 16(3) provides that whenever an employer is consulting or bargaining with a representative union, he must disclose all relevant information that will allow the union to engage effectively in consultation or collective bargaining. There is a similar provision in section 89(1) in respect of the functioning of workplace forums.

The responses to Question 7 'At what stage/when will your organisation disclose information to a trade union?' also demonstrated a wide variety of practices. The most common practice reported by management and by worker representatives was disclosure during wage negotiations. Other responses by management included 'when deemed 
necessary by management', 'on a need to know basis' and 'when compelled by law' and 'only after salary negotiations have been concluded'. Ngobo and Howard (1999:9) refer to the reluctance of employers to disclose information as 'minimal compliance'.

This reluctance to disclose information has the potential to cause disputes and this was probed by question 8 which asked 'Has your organisation had a dispute relating to disclosure of information?' One of the worker representative stated that these disputes were 'on-going - every year we experience the same kind of problems to obtain information'. In contrast only two management representatives reported disputes about disclosure of information - in both cases involving financial information. A possible explanation of this dichotomy is that worker representatives experience greater frustration from management while the latter have yet to come to terms with disclosing of information as now required by the LRA.

To Question 9 'How were disputes resolved? What process was followed?' the representatives of both sides reported making use of the conciliation and/or mediation or arbitration services of the CCMA or resolving the disputes by internal negotiations between the employer and the trade union. However, the same response was given in only two cases, which is an indication of how differently matters are viewed by management and worker representatives.

\section{Conclusions}

Bearing in mind South Africa's past in which concealment rather than disclosure of information was the norm, the strides made with the new openness regarding access to information for South African citizens can be described as quite remarkable. In the work environment, in particular, the LRA of 1995 provides for the first time for disclosure of information by employers to employees. However, there are still reluctance and resistance to providing various types of information which were previously considered as belonging to the domain of management. Dr Leon Wessels, a Commissioner of the SAHRC has also recently expressed his concern about the hostility and ignorance still displayed by many parties towards the disclosure of information in terms of the Promotion of Access to Information Act (The Guide on how to use the promotion of Access to Information Act: 4)

The study described in this article indicated that there was universal support amongst the participants for the principle of disclosure of information. Differences between the parties occur about the type of information to be disclosed and the timing of such disclosure. The employer side is concerned about erosion of management prerogatives and commercial confidentiality while the employee side wants information disclosure because it enhances their negotiating capacity and their potential for joint decision-making at the workplace. The fact that many disputes between management and workers emanate from problems in regard to disclosure of information indicates that both sides need to work hard on developing a spirit of trust and cooperation with the other side. In view of our long history of adversarial labour relations this is likely to take a long time to evolve.
There was agreement between the parties that requests for information should come from the worker representatives. From this it appears that employees are not making efficient use of Section 16 and Section 89(1) of the LRA which, respectively, provide that an employer must disclose all relevant information to a representative trade union or to a workplace forum to enable them to effectively perform their functions. It is a weakness of the LRA that the Act is not more specific and prescriptive about when information must be provided. The voluntary disclosure and sharing of information by employers prior to and during collective bargaining and participation by employees in decisionmaking would undoubtedly improve and consolidate a trust relationship between employers and trade unions/employees.

Grosett (1997) found that employers in his study reported that information disclosure was conducive to improved collective bargaining, to increased employee involvement in decision-making and to reduced conflict in their organisations. The current study has produced similar responses but a significant variation is that in this instance the responses came from employer as well as employee representatives in the same organisations. However, a telling difference between these two groups of respondents was that worker representatives were of the opinion that insufficient information was being disclosed by employers. This is certainly an aspect of disclosure and information sharing which needs to be attended to.

It appears to be imperative for the enhancement of industrial democracy in South African organisations, that a mutually acceptable procedure be developed between the national representatives of business and labour on all aspects of disclosure of information which have given or are likely in future to give rise to disputes. Greater clarity is needed, for example, on the timing of disclosure of information; on its relevance and sufficiency and on what information can reasonably be expected from employers to share with their employees.

South African organisations will only achieve success and growth if suspicion and mistrust between management and labour are eradicated. One of the most powerful means of accomplishing this and then reaching mutual understanding and common objectives is the sharing of information. It is therefore of the utmost importance that management and trade unions give urgent attention to this vital aspect of industrial relations.

\section{References}

Brand, J. \& Cassim, N.A. 1980. 'The duty to disclose - a pivotal aspect of collective bargaining', Industrial Law Journal, 1(4):249-259.

Ballace, J.R. \& Gospel, H.F. 1983. 'Disclosure of information to trade unions: A comparative perspective', International Labour Review, 22 (1): 57-74.

Barnard, J. 2005. 'Deadline near for compliance with new access to info act', The Herald (EP Herald), 16 August :11. 
Carby-Hall, J.R. 2006. 'The Charter of Fundamental Rights of the European Union -the social dimension', Managerial Law, 48(4): 430-446.

Creswell, J.W. 1998. Qualitative inquiry and research design: Choosing among five traditions. Thousand Oaks, California: Sage.

Devenish, G.E. 1998. A commentary on the South African Constitution. Durban: Butterworths.

De Vos, A.S., Strydom, H., Fouché, C.B. \& Delport, C.S.L. 2005. Research at grass roots: For the social sciences and human services professions. $3^{\text {rd }}$ Edition. Pretoria: Van Schaik.

Dubin, R. 1954. 'Constructive aspects of industrial conflict'.

In Kornhauser, A. Dublin, R. \& Ross, A.M. (Eds.). Industrial conflict. New York: McGraw -Hill.

Du Toit, D., Woolfrey, D., Murphy, J., Godfrey, S., Bosch, D. \& Christie, S. 1998. The Labour Relations Act of 1995. $2^{\text {nd }}$ Edition. Durban: Butterworths.

Du Toit, D., Woolfrey, D., Murphy, J., Godfrey, S., Bosch, D. \& Christie, S. 2000. The Labour Relations Act of 1995. 3rd Edition. Durban: Butterworths.

Everingham, G.K. 1991. 'Financial reporting to employees', Accounting South Africa, August: 217.

Grosett, M. 1997. 'Management perceptions of the effect of the disclosure of company information to employees: results of an empirical study', South African Labour Relations Journal, 21(3): 43-58.

Holovach, R. 2005. 'Cities pass resolution in opposition to the Patriot Act, Nation Cities Weekly, 28 (29) : 4. [online] URL: EBSCOHost: Business Source Premier: http://0web10.epnet.com/ Accessed :2005/09/14.

International Labour Organisation (ILO) 1981. Collective bargaining recommendations. Geneva: ILO.

Johannessen, L. 1995. 'A motivation for legislation on access to information', South African Law Journal, 11(2): 85-115.

Jordaan, B. 1996.' Disclosure of information in terms of the Labour Relations Act', Labour Law News, 6(1): 17-39.

Kahn-Freund, O. 1977. Labour and the law. 2nd Edition. London: Stevens.

Kollapen, N.J. 2005. 'The guide on how to use the Promotion of Access to Information Act - Act 2 of 2000. [online] URL: http:// www.sahrc.org.za. Accessed 2005-0812.

Landman, A.1996. 'Labour rights to employee information', Contemporary Labour Law, 6(3):32.

Lincoln, Y. \& Guba, E. 1985. Naturalistic inquiry. Beverly Hills, CA: Sage.
Miles, M.B. \& Huberman, A.M. 1984. Qualitative data analysis: A source book of new methods. London: Sage Publications.

Miles, M.B. \& Huberman, A.M. 1994. Qualitative data analysis: A source book of new methods. London: Sage Publications.

Monteiro, A. 2005. Extension for Access to Information Act, Citizen , 1 September: 25.

Ngcobo, H. \& Howard, H. 1999. 'Disclosure of information', South African Labour Bulletin, 23(6):6-11.

Punch, K.F. 2005. Introduction to social research: Quantitative and qualitative approaches. London: Sage Publications.

Roberts, B.C. \& Liebhaberg, B. 1977. 'International regulation of multi-national enterprises: Trade union and management concerns', British Journal of Industrial Relations, XV (3): 356-373.

Streek, W. 1994. 'Co-determination and trade unions', South African Labour Bulletin, 18(5): 87-95.

Van der Walt, R.v.M. 2002 'The democratisation of the workplace in some South African organisations'. Unpublished doctoral thesis. Pretoria: University of Pretoria.

Wood, G. \& Mahabir, P. 2001.'South Africa’s Workplace Forum system: A stillborn experiment in the democratisation of work', Industrial Relations Journal, 32(2):230-243.

\section{ACTS}

South Africa. 1996. Constitution of the Republic of South Africa Act No 108 of 1996. Pretoria: Government Printer.

South Africa. 1995. Labour Relations Act No 66 of 1995. Pretoria: Government Printer.

South Africa. 2000. Promotion of Access to Information Act No 2 of 2000. Pretoria: Government Printer.

UK. Employment Protection Act of 1975 (EPA1975), Legislative Series, 1975-UK 2. [online] URL: http//www.eurofound.eu..int/ [Accessed :2005/09/14]. 
